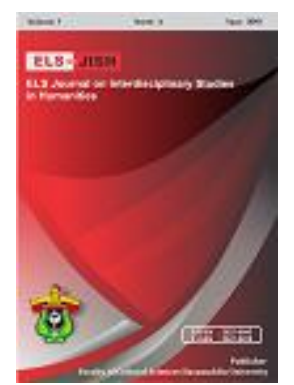

ELS-JISH

ELS Journal on Interdisciplinary Studies on Humanities

Volume 2 Issue 4, 2019

ISSN (print) : 2621-0843

ISSN (online) : 2621-0835

Homepage : http://journal.unhas.ac.id/index.php/jish

\title{
English Vowels and Diphthongs Problems of Sundanese Learners
}

\author{
Kuntum Palupi Setyaningsih ${ }^{1}$, Agus Wijayanto ${ }^{2}$, Suparno ${ }^{3}$ \\ ${ }^{1}$ kuntumpalupi10@student.uns.ac.id
}

\begin{abstract}
EFL Sundanese learners encounter the difficulties in English pronunciation. The learners are often unable to differ between English vowel sounds long [i:] with short [I] like the word cheese they pronounce it as / $/ \mathrm{I} / \mathrm{z} /$ instead of $/ \mathrm{t} \mathrm{f}: \mathrm{z} /$, despite they have learned English since elementary school, officially they have learned English for around 5 years. The purpose of this study is to explore the interference of mother tongue in pronunciation field that was made by Sundanese learners dealing with English vowels and diphthongs. The participants were 30 EFL learners with Sundanese background as their mother tongue. The data were collected by recording the students' pronunciation and analysed using contrastive analysis. The results demonstrate that the learners met obstacles in uttering English vowels [i:],[u:],[0], and diphthongs[er],[əひ],[æ]. The dominant mispronunciation of the English sounds occurs because of the absence of those English sounds in the learners' mother tongue. This paper offers some recommendations to the teachers to overcome the phenomenon mother tongue interference.
\end{abstract}

Keywords: First Language; Interference; Language; Pronunciation

How to cite: Setyaningsih, K. P., Wijayanto, A., \& Suparno (2019). English Vowels and Diphthongs Problems of Sundanese Learners. ELS Journal on Interdisciplinary Studies in Humanities, 2(4), 571 581

\section{Introduction}

The status of English in today's issue has expanded into a global language. Its significance is being noted in almost every sphere of everyday life and its knowledge is becoming more and more essential. Crystal (2003:2) tells that wherever you travel, you see English signs and advertisements. Wherever you enter a hotel or restaurant in a foreign city, they will understand English, and there will be an English menu. Communication in English on an international basis has turned into a worldwide phenomenon. Furthermore, English becomes the requirement subject that should be grasped by the students according to the Structure of Curriculum issued by Indonesian Minister of Education (2013). The students are expected to be able to communicate in English and use it as knowledge to face the development of English globalization in the usage after they graduate from school at least with some skills that have been thought in school. One of skills that should be learned by the students is speaking skill. Speaking is the most crucial component of language skill (Nunan, 1995). Speaking is used as a tool to communicate or to deliver the message through

1,2,3 Universitas Sebelas Maret, Indonesia 
spoken language. However, the students' speaking skill can be influenced by some factors like linguistics factors namely vocabulary, grammar, and pronunciation. Hago and Khan (2015) argue that pronunciation rests as the most essential part in learning English. Practically, there are a lot of students who still suffer from pronunciation problems. There are still many students who mispronounced English sounds. This case may cause misunderstanding among the speakers and the listeners. Goh (2007) conveys that the speakers' message may not be delivered well to the listeners if the speaker get mispronounce the sounds. The difficulties in pronunciation may affect the learners' failure to get the message that is delivered to them (Hewings, 2004). Moreover, the intention of speaking is not only just turning out the words through the mouth but also conveying the message to the audience. Yates (2002) argues that the students with good pronunciation are better than them who have bad pronunciation, even if their grammar is perfect. The students with clear pronunciation will deliver the message well to the audience even though they make some grammar mistakes. Fraser (2000a, p.7) via Gilakjani (2011) conveys that "with good pronunciation, a speaker is intelligible despite other errors; with poor pronunciation, understanding a speaker will be very difficult, despite accuracy in other areas. Thus, pronunciation becomes essential in spoken communication (Burns, 2003). This means that investigating the learners' errors in pronunciation is valuable to reveal the information concerning the learners' problems. These help the teachers to anticipate the learner's troublesome in pronunciation and to improve their ability. So that, by having accurate pronunciation ability the learners' are able to convey the message well and be able to gain good communication.

EFL Sundanese learners encounter the difficulties in English pronunciation. The learners are often unable to differ between English vowel sounds long [i:] with short [I] like the word cheese they pronounce it as $/ \mathrm{t} \mid \mathrm{I} z /$ instead of $/ \mathrm{t}[\mathrm{i}: \mathrm{z} /$, despite they have learned English since elementary school, officially they have learned English for around 5 years. This problem exists because there are differences sound system among English and Sundanese. In English sound system there are sounds that should be pronounced in long way namely long [i:] and long [u:]. In another hand, Sundanese sound systems do not provide those sounds. According to Fromkin, et al (2017) there is 10 vowels and 5 diphthongs in English phonological system. Conversely, Sundanese only has 6 vowels and 1 diphthong (Tamsyah, 2001). The significant difference between English and Sundanese sounds system affect the learners' performance in pronouncing the English words. Maros, et al (2007) claims that the structures of the learners' mother tongue that are different from the target language cause the negative transfer due to the transfer of old habits into the target language. Lado (1957:2) believes that "individuals tend to transfer the forms and meanings, and the distribution of forms and meaning of their native language and culture to the foreign language and culture". In addition, Oddlin (1989:27) states that "transfer is the influence resulting from similarities and differences between the target language and any other language that has been previously (and perhaps imperfectly) acquired". The learners will tend to use familiar sounds and sounds pattern of their mother tongue when they hear a foreign language (Wells, 2000). Thus, the sounds that are produced by the learners may different from how it sounds when uttered by the native speakers. The learners' mother tongue interferes to function in target language. Zhao (2019) conveys that negative transfer arises when the knowledge of mother tongue disrupts the performance of the target language. He believes that the 
learners' mother tongue sometimes cannot promote to learn a foreign language that's why interference may take place in the process of learning English. Negative transfer occurs when the learners put their knowledge of mother tongue in understanding the target language and substitute the target language knowledge with their mother tongue form. However, the learners' acquires mother tongue since they birth and it is used as a tool for communication among their social. Ellis (1997) defines interference of mother tongue as 'transfer' that's the influence that the learners' first language exerts over the process of acquiring the target language. He argues that the learners construct their own interim while learning the target language because they have their own perception about what is transferable toward the target language.

Extensive research has been done in the field of interference of mother tongue. Pal (2013) attempted to identify interference of Hindi in the process of acquiring English. He found that the major problem met by the speakers of Hindi was fricative sounds, namely, [], [dz],[z],[3]. Hu (2015) revealed that Chinese immigrants' mother tongue interfere their English speaking. He explained that the interference happens because of the distinctions of phonological system between Chinese and English. Bardakçi (2015) discovered that Turkish EFL teachers encounter dominant mispronunciation of the sound schwa [ə] along with other sounds such as $[\theta],[\eta]$, and [æ]. The absence of the corresponding sounds of $[\theta]$ and [æ] in Turkish could be deemed the reason for such pronunciation problems.

This study was conducted to find the problems and try to overcome them so that they could be anticipated effectively. This study lights on the pronunciation errors of the students with Sundanese background in uttering English vowel and diphthong sounds. This study investigated the English vowel and diphthong sounds because they appear to be more problematic among the students rather than the consonant sounds. The errors that happen to the learners give us the awareness as a diagnostic tool to overcome the problems.

\section{Method}

The type of this research is a qualitative research. Babu (2008) explains that qualitative research method was developed in the social sciences to enable researchers to study social and cultural phenomena: observe feelings, thoughts, behaviours and the belief of the mass society. Furthermore, Denzin and Lincoln (2005) describe qualitative research as a multifaceted research method involving an interpretative, naturalistic approach to subject matter. The multifaceted nature of qualitative research enables researchers to develop a holistic picture of the phenomenon in question. Yin (1993) distinguishes three types of case studies: exploratory, causal and descriptive case studies. This study uses a descriptive case study as the type of the research since this study focus on describing the learners' problems with Sundanese background in pronouncing vowels and diphthongs sounds. The descriptive nature of qualitative research allows the researcher to provide a description of the experiences of the participants, which will either sustain or confront the theoretical assumptions on which the study is based (Meyer, 2001). The descriptive nature of qualitative research enables readers to understand the meaning attached to the experience, the distinct nature of the problem and the impact of the problem (Mohajan, 2018). Therefore, a descriptive research is designed to obtain information concerning the current status of phenomena. They are directed toward determining the nature of a situation as it exists at the time of the study. The 
aim of descriptive study is to describe what exist with respect to variables or conditions in a situation. This research is a descriptive qualitative study because it concerns with the natural context of students' pronunciation.

In this study, the data were collected from 30 students of SMK Komputama Majenang. The entire samples have Sundanese language as their mother tongue. The instrument is a designed text with the consideration in the possibilities of mother tongue interference in some vowel and diphthong sounds. An audio recording was used to take the students' pronunciation. Wei (2002) as cited in Hassan (2014) uses an audio recording to investigate the Thai students' errors in pronunciation. The data were analyzed by using contrastive analysis theory. Thyab (2016) argues that contrastive analysis is used to unveil the problems of some features are more challenging than others in the acquisition of the target language. He explains that the hypothesis of contrastive analysis is based on the claim that the distinction between the learners' first language and their target language causes the difficulty in the process of acquiring the target language. Furthermore, the more significant difference of the first language with the target language the more problematic that the learners will meet.

The research procedure, firstly, the data were extracted into board transcription. After the data were transcribed, they were exposed as can be seen in the results and discussion. The next step was triangulation the data got from the recording with the checklist. Triangulation was used in this study to crosscheck the data to get high validity and reliability.

\section{Findings and Discussion}

This part reveals the results of the exploration and provides a detailed analysis of the data interpretation. The data of this research were English words that had been uttered inaccurately by the Sundanese learners. The data were gathered through recording during the learners' activity in reading aloud. The data collections were assembled as follows:

Table 1. The learners' errors in producing sound [er]

$\begin{array}{lcc}\text { English } & \text { Phonetics } & \begin{array}{c}\text { Students' } \\ \text { Words }\end{array} \\ \text { Transcription } & \text { Pronunciation }\end{array}$

\begin{tabular}{|c|c|c|}
\hline Make & / meIk / & /mek/ \\
\hline Bake & / berk / & /bek/ \\
\hline Baby & / 'beibi / & /bebI/ \\
\hline They & / ðег/ & /dey/ \\
\hline Day & / deI / & /dey/ \\
\hline Dangerous & /deindzras / & /dengeros/ \\
\hline Came & /keim/ & /kem/ \\
\hline Break & /breik/ & /brek/ \\
\hline Safe & /serf/ & /sef / \\
\hline Made & $/$ meid/ & $/ \mathrm{med} /$ \\
\hline Way & /weI/ & /wey/ \\
\hline Raisins & /'reiznz/ & /raIsin/ \\
\hline Latest & /'leitıst/ & /letes/ \\
\hline
\end{tabular}




\begin{tabular}{cll}
\hline Stay $/$ stei/ & /stey / \\
\hline
\end{tabular}

Table 2. The learners' problem with sound [æ]

\begin{tabular}{|c|c|c|}
\hline $\begin{array}{l}\text { English } \\
\text { Words }\end{array}$ & $\begin{array}{c}\text { Phonetics } \\
\text { Transcriptio } \\
\mathbf{n}\end{array}$ & $\begin{array}{c}\text { Students' } \\
\text { Pronunciation }\end{array}$ \\
\hline Had & / hæd / & /hed/ \\
\hline And & / ænd / & /end/ \\
\hline As & /æz / & les/ \\
\hline That & / ðæt/ & /tet/ \\
\hline Having & /'hævin/ & /hefing/ \\
\hline Animals & / 'æniməlz / & /enimal/ \\
\hline Drank & /dræりk/ & /dreng/ \\
\hline Back & /bæk/ & /bek/ \\
\hline Trap & /træp/ & /trep/ \\
\hline Sat & /sæt/ & /set/ \\
\hline Mad & $/ \mathrm{mæd} /$ & $/ \mathrm{med} /$ \\
\hline Managed & /'mænıdzd/ & /menej/ \\
\hline Ankle & /'æhkl/ & /engkel/ \\
\hline Happy & /'hæpi / & /hepi/ \\
\hline Mashed & /mæft/ & /mas/ \\
\hline Cats & /kæts/ & /ket/ \\
\hline Rabbits & /'ræbits/ & /rebit/ \\
\hline Crackers & /'krækəz/ & /kreker/ \\
\hline
\end{tabular}

Table 3. The learners' errors in pronouncing sound [av]

\begin{tabular}{|c|c|c|}
\hline $\begin{array}{l}\text { English } \\
\text { Words }\end{array}$ & $\begin{array}{c}\text { Phonetics } \\
\text { Transcription }\end{array}$ & $\begin{array}{c}\text { Students' } \\
\text { Pronunciation }\end{array}$ \\
\hline House & / havz/ & / hous/ \\
\hline Both & / bəu $\theta$ / & / bot/ \\
\hline Howled & /havld / & / howled/ \\
\hline Out & / avt/ & / out/ \\
\hline Told & / təuld / & /told/ \\
\hline Donated & / dəv'neitid / & /donated/ \\
\hline Carried & / kærid / & /kerid/ \\
\hline So & /səu / & $/ \mathrm{so} /$ \\
\hline Down & / daun/ & /don/ \\
\hline Home & / həum/ & /hom/ \\
\hline Ground & /graund/ & /gron/ \\
\hline Know & /nəv/ & /now/ \\
\hline Sounds & /saundz/ & /son/ \\
\hline Counter & /'kauntə/ & /konter/ \\
\hline
\end{tabular}


Table 4. The learners' obstacle with phoneme long [i:]

\begin{tabular}{|c|c|c|}
\hline $\begin{array}{l}\text { English } \\
\text { Words }\end{array}$ & $\begin{array}{l}\text { Phonetics } \\
\text { Transcription }\end{array}$ & $\begin{array}{c}\text { Students' } \\
\text { Pronunciation }\end{array}$ \\
\hline Beans & / bi:nz/ & /bIns/ \\
\hline Sneeze & /sni:z/ & /snIs/ \\
\hline Sheep & / fi:p/ & /sip/ \\
\hline Please & / pli:z/ & /plis/ \\
\hline She & / fi:/ & $/ \mathrm{SI} /$ \\
\hline Refried & / ri:'fraid// & /refrid/ \\
\hline Cheese & /tfi:zl & /CIS/ \\
\hline Seasoning & /si:znIn/ & /sisenIng/ \\
\hline
\end{tabular}

Table 5. The learners' problem with phoneme long [u:]

\begin{tabular}{ccc}
\hline $\begin{array}{c}\text { English } \\
\text { Words }\end{array}$ & $\begin{array}{c}\text { Phonetics } \\
\text { Transcription }\end{array}$ & $\begin{array}{c}\text { Students' } \\
\text { Pronunciation }\end{array}$ \\
\hline Room & $/$ ru:m/ & $/$ rum/ \\
\hline Food & $/$ fu:d/ & $/$ fud/ \\
\hline Zoo & $/$ zu: / & /zu/ \\
\hline Too & $/$ tu:/ & $/$ tu/ \\
\hline Juice & $/$ dzu:s / & /jus/ \\
\hline Spoon & $/$ spu:n/ & $/$ spun/ \\
\hline Movies & $/$ mu:viz / & /mufis/ \\
\hline
\end{tabular}

Table 6. The learners' errors in uttering sound [0]

\begin{tabular}{ccc}
\hline $\begin{array}{c}\text { English } \\
\text { Words }\end{array}$ & $\begin{array}{c}\text { Phonetics } \\
\text { Transcription }\end{array}$ & $\begin{array}{c}\text { Students' } \\
\text { Pronunciation }\end{array}$ \\
\hline Walk & / wo:k/ & /wolk/ \\
\hline Water & /'wo:tə/ & /woter/ \\
\hline All & $/$ o:l/ & $/$ ol/ \\
\hline Mall & $/ \mathrm{mo:l/}$ & $/ \mathrm{mol} /$ \\
\hline Taught & $/ \mathrm{to}: \mathrm{t} /$ & $/$ taut/ \\
\hline For & $/$ fo:/ & $/$ for/ \\
\hline Always & /'o:lweIz/ & /olwes/ \\
\hline Also & /'o:lsəo/ & /also/ \\
\hline Spoiled & /spo:Ild/ & /spoild/ \\
\hline
\end{tabular}

According to the collected data of the learners' mother tongue interference that was occurred among Sundanese students in learning English, these were being described as follows:

1. Sundanese learners' problem in pronouncing [er]. Practically, the students were accustomed to pronounce sound [e] instead of [er]. They made errors by changing the sound [er] into [e]. Sound [e] is available in Sundanese language, for example, the sound [e] in Sundanese language as in the word awewe $\rightarrow$ girl. In this case, the learners made errors in uttering the English word dangerous, they uttered it as /dengeros/ when it should be pronounced as /derndzros /. The learners changed the sound [er] into the familiar sound [e] because the diphthong [eI] is not provided on their mother tongue language system. 
2. Sundanese learners' errors in uttering phoneme [æ]. The learners changed [æ] sound with [e] sound. They pronounced the word animals $\rightarrow$ /enimal/ instead of /'ænIməlz/. Sound [æ] were acquired by the learners as similar to sound [e] in the process of learning. Hence, they utter with the sound [e] instead of [æ].

3. The interference of mother tongue occurred for the learners in pronouncing [av] sound. The learners tend to shift the sound [av] with [o] sound as they were familiar with the sound. They pronounced the word home $\rightarrow / \mathrm{hom} /$ where it should be uttered / houm/.

4. Problem in pronouncing vowel long [i:]. The learners uttered the word cheese $\rightarrow /$ cis/ instead of $/ \mathrm{t}$ [i:z/. They have the tendency to utter the sound [i:] with [i]. It is understandable for the fact that the students with Sundanese background tend to change the sound because, in the Sundanese sound systems, sound [i:] is not available. Hence, they have problem to differ the English sound with long [i:] and short [i]. The phonological system of Sundanese language which is only provide short vowel makes the learners practice the same habit when they have to pronounce English vowels. They met the obstacles in deciding when they have to pronounce the English words in short or long vowels. However, English sounds should be pronounced accurately because different sound may cause different understanding. For example, the word bin / bin/ and bean /bi:n/. Those words may cause misunderstanding if the learners cannot distinguish those sounds when pronouncing them. This can cause a lot of problems for non-native speakers of English and they sometimes get confused in producing the English.

5. Problem in pronouncing vowel long [u:]. The nonexistence sounds with long [u:] made the learners pronounced it with short $[u]$ as it provided on their mother tongue language system. They uttered the word spoon $\rightarrow$ /spun/ where it should be /spu:n/. The learners encountered the difficulty to distinguish between long [u:] and short [u]. in Sundanese language, vowel [u:] is not exist.

6. Problem in pronouncing vowel [0]. The learners change the phoneme [0] with [0] sound as in the word walk, they pronounced it /wolk/ instead of / wo:k/.

It is understandable that the learners met the obstacles in pronouncing some English vowels and diphthongs, while only six vowels and one diphthong in Sundanese language are available, namely, a, i, u, e, é, o, and eu (Tamsyah, 2010). However, the learners did not accustom with English phonemes which have ten vowels and five diphthongs (Fromkin et al, 2017). Unconsciously, the learners' first language interfered their way in producing English words. The Shifting of some English phonemes could not be avoided by the Sundanese learners.

The demand of mastering English language as the world's international tool in communication requires the learners to have good English proficiency. As the part of linguistics component, pronunciation takes the essential role to be accomplished by the learners. In fact, Sundanese learners met big problems related to mother tongue interference particularly in the scope of pronunciation. They have a habit to transfer their mother tongue knowledge in the process of target language acquisition. Derakhshan and Karimi (2015) believe that when the learners are asked to speak they incline to transfer the forms of their mother tongue to the target language. The phonological difference between Sundanese and English language becomes the crucial issue to the learners. The pronunciation fossilization shades the learners' way 
in uttering English words. The fossilization is the effect of the frequent incorrect phonological errors done by the learners in the process of learning the target language (Wei, 2008). Thus, the learners are suffering to be able to understand the phonological difference between their mother tongue and English.

\section{Conclusion}

According to the result above, it can be drawn the conclusion that the learners have obstacles in producing English sounds. The interference of mother tongue of Sundanese learners in learning English made them difficult in uttering some English phonemes, especially in vowel and diphthong sounds. The learners way to utter English phonemes are deeply influenced by their mother tongue. However, the sounds between English and Sundanese are very different. The problems of students pronunciation are in the phonemes [ei], [æ], [av], [i:], [u:], and [0]. Those sounds are not provided in their mother tongue language system. The non-existence of a particular sound of English in the elarners' mother tongue can therefore drive them to substitute the sounds which are near to their mother tongue. Thus, they tend to transfer it into the familiar sound on their language systems. Since the learners have Sundanese language and use it as a daily life communication tool, so it is obviously exposed that they meet it difficult to utter the phonemes that are not exist on their mother tongue. Moreover, the learners keep making errors in uttering English sounds. This error will be fossilized, but if the teachers make correction to the learners' pronunciation, they will pronounce correctly. Selinker (1972) via Wei (2008) believed that fossilization is led by the existence of transfer from the learners' mother tongue.

After conducting this study and the errors have been discovered by the analysis, it is hoped that the English teachers can give more attention in teaching those English sounds as the learners appear to be inclined more by their mother tongue. For this reason, the teachers can enlighten differences between Sundanese and English sounds in order to be easy for the students to understand how English sounds pronounced. To support this, Zhang and Yin (2009) purposes that the presentations of distinctions between the learners' first language and their target language in phonological system may raise awareness in way that may beneficial to the process of acquiring the target language to avoid error in pronunciation. However, the interference of mother tongue is not only rising in pronunciation. Several experts have been conducted the interference of mother tongue in the area of writing, they are Abu Seileek (2006), Karim and Nasajji (2013), and Zhao (2019). Thus, the teachers should have linguistics knowledge and deliver it to the learners, so they are able to realize the causes of their problems and have more awareness to practice English harder. The teachers may design pronunciation activity which is friendly to do by the learners as regards to correcting errors interfered by their mother tongue suitable with the learners' needs as the ethnic group (Sundanese).

This study doesn't explain stress and intonation problems of the learners. The other researchers can take this gap to investigate about these issues. In additional, the future research may use more data to gain more detailed pronunciation problems of the learners. It is highly expected that the findings gained by other researchers related to the first language interference will help us, especially for the teachers to design better method in teaching pronunciation to the learners, thus the learners are able to master English language well. 


\section{Acknowledgments}

First and foremost, I would like to express my highest gratitude to Allah SWT, the almighty for the endless blessing and mercy for every single thing happen in my life. I would like to express my gratitude to Mr. Agus Wijayanto as the first advisor for her guidance and suggestion during the completion of this journal. I also would like to express my greatest appreciation to Mr. Suparno as the second advisor for her willingness to guide and correct this journal.

\section{References}

AbuSeileek, A. F. (2006). The Use of word processor for teaching writing in EFL learners in King Saud University. Journal of King Saud University.

Ali Derakhshan, Elham Karimi. (2015). The Interference of First Language and Second Language Acquisition. Theory and Practice in Language Studies, 10, 2112-2117.

http://dx.doi.org/10.17507/tpls.0510.19

Bardakci, M. (2015). Turkish EFL pre-service teachers' pronunciation problems. Educational Research and Reviews, 10, 2370-2378. doi:10.5897/ERR2015.2396

Burns, A. (2003). Clearly speaking: pronunciation in action for teachers. National Center for English Language Teaching and Research, Macquaire Universaity, Sydney NSW 2109, 5

Crystal, D. (2003). English as a global language Second edition. Cambridge University Press, New York.

Denzin, N. K. (2015). Triangulation. The Blackwell Encyclopedia of Sociology.doi:10.1002/9781405165518.wbeost050

Ellis, R. (1994). The Study of Second Language Acquisition. Oxford: Oxford University

Fromkin, V., Rodman, R., \& Hyams, N. (2017). An Introduction to Language (11th ed). Boston: Thomson.

G. Ramesh Babu. (2008). Research Methodology in Social Sciences India:Concept Publishing Company.11Press.

Gilakjani, A. P. (2011). A study on the situation of pronunciation instruction in ESL/EFL classrooms. Journal of Studies in Education, 1(1),1-15

Goh, C. C. M. (2007). Teaching speaking in the language classroom. Singapore: SEAMEO Regional Language Centre.

$\mathrm{Hu}$, Chaowei (2015). "Mother Tongue Interference in English Language Pronunciation of the Chinese Immigrant in the United States".Master's Projects and Capstones. 218.https://repository.usfca.edu/capstone/218

Hassan, E. M. I. (2014). Pronunciation problems: a case study of English language students at Sudan University of Science and Technology. English Language and Literature Studies 4 (4). 
Hago, O. \& Khan, W. (2015).The Pronunciation Problems Faced by Saudi EFL Learners at Secondary Schools. Education and Linguistic Research. 1, 2. Available at http://dx.doi.org/10.5296/elr.v1i2.7783

Hewings, M.,(2004). Pronunciation Practice Activities: A Resource Book for Teaching EnglishPronunciation, Cambridge, Cambridge University Press

Karim, K., \& Nassaji, H. (2013). First language transfer in second language writing: An examination of current research.

Iranian Journals of Language Teaching Research, 1(1), 117-134.

Lado, R. (1957). Linguistics across Cultures. Ann Arbor: University of Michigan Press.

Maros, Marlyna \& Tan, Kim Hua \& Salehuddin, Khazriyati. (2007). Interference In Learning English: Grammatical Errors In English Essay Writing Among Rural Malay Secondary School Students In Malaysia. 2.

Mohajan, Haradhan K. (2018). Qualitative research methodology in social sciences and related subjects. Journal of Economic Development, Environment and People, 7(1), 23-48.

Nunan, D. (1995). Language Teaching Methodology: A Textbook for teachers. NY: Phoenix Ltd., p.593.

Odlin, T. (1989). Language Transfer: Cross-linguistic Influence in Language Learning. Cambridge: Cambridge University Press.

Pal, S. (2013). Mother tongue influence in spoken English. Intenational Conference "ICT for

language learning" 6th ed. Retrieved from http: //conference.pixelonline.net/ICTLL2013/

Tamsyah, D.R. (2010).Galuring Basa Sunda.Bandung: CV. Pustaka Setia.

Thyab, R.A. 2016. "Mother-Tongue Interference in the Acquisition of English Articles by L1 Arabic Students." Journal of Education and Practice 7 (3):1-4. www.iiste.org/Journals/index.php/JEP/article/download/28410/29153.

Wei, Xueping. (2008). Implication of IL Fossilization in Second Language Acquisition. English Language Teaching 1/ 1: www.ccsenet.org/journal.html. Accessed July 3, 2019.

Wells, J. C. (2000). Overcoming phonetic interference. English Phonetics, Journal of the English Phonetic Society of Japan, 3, 9-21.

Yates, L., (2002). What is pronunciation?- Adult Migrant English Program (AMEP) Research Centre Fact Sheets, Sydney, National Centre for English Language Teaching and Research, Macquarie University, Retrieved from http://www.ameprc.mq.edu.au/docs/fact_sheets/01Pronunciation.pdf

Yin, R. K. (1993). Applications of case study research. Newbury Park, CA: Sage Publications. 
Zhang, F., \& Yin, P. (2009). A study of pronunciation problems of English learners in China. Asian Social Science, 5(6). Retrieved from http://www.ccesnet.org/journal.html

Zhao, Y. N. (2019).Negative Transfer of Mother Tongue in English. Creative Education, 10, 940-946.https://doi.org/10.4236/ce.2019.105070 